\title{
TAXONOMIC AND NOMENCLATURAL NOTES ON PHILIPPINE FERNS. I. THE IDENTITY OF ASPLENIUM ANISODONTUM C.PRESL ( ASPLENIACEAE)
}

\author{
A. E, SALGADO*
}

\begin{abstract}
The synonymy of Asplenium anisodontum C.Presl (Aspleniaceae) in the Philippines is clarified. Asplenium anisodontum C.Presl. A. longissimum Blume and A. caudatum G.Forst. are different species. A. anisodontum C.Presl and A. longissimum Blume are both found in the Philippines. The presence of Asplenium caudatum G.Forst. in the Philippines is doubtful. Asplenium acutiusculum Blume is the same as A. longissimum Blume and the latter name should be accepted.
\end{abstract}

Keywords. Asplenitum caudatum, Filicinae, Malesia, Pteridophyta.

\section{INTRODUCTION}

In studying the taxonomic history of Philippine Aspleniaceae, it became clear that the synonymy of several species is confusing and in need of clarification. During the summers of 1994 and 1995 the author had the opportunity to study the type specimens and numerous other Philippine Aspleniaceae housed at Kew (K), The Natural History Museum, London (BM) and Leiden (L).

Copeland (1960) states in his Fern Flora of the Philippines that Asplenium anisodontum C.Presl has been considered by some modern authors to be the same as Asplenium acutiusculum Blume. He doubts the correctness of this idea. Christensen (1905) and Holttum (1968) consider Asplenium anisodontum C.Presl a synonym of Asplenium acutiusculum Blume. Price (1982) considers the holotype of A. acutiusculum Blume to be a smaller plant of $A$. longissimum Blume. Since both $A$. acutiusculum and A. longissimum were included by Blume (1828) on the same page, Price (1982) designated $A$. longissimum as the name of the species.

\section{ASPLENIUM ACUTIUSCULUM AND A. LONGISSIMUM}

The Rijksherbarium at Leiden has the holotypes for both A. longissimum and $A$. acutiusculum. The holotype of $A$. longissimum Blume consists of a single sheet with a fertile frond section (the rhizome and stipe are missing), from Borneo, and without a collection number. There is a note from Price: "agreeing in all details with description, which only lacks the stated source, Borneo'. Another note from Rosenstock says: 'Asplenium longissimum, 1915'. Two numbers can be seen on the sheet: 'Herb. Lugd. Bat. No. 922.167-1020' and 'Leiden 5059 No. 54'.

\footnotetext{
* School of Sciences. Christian Brothers University, 650 East Parkway South, Memphis. TN 38104, USA.
} 
The holotype of Asplenium acutiusculum has Blume's name on it but no collection number. It consists of a single sheet with five sections of the lamina, without stipe or rhizome. Each section is almost the full length of the sheet; one is the frond apex. A note by Price says: 'matching the description in all details'. There is also a note from Rosenstock, 1915, naming it Asplenium longissimum. Again two numbers appear on the sheet: 'Herb. Lugd. Bat. 908.311-892' and 'Leiden 5059 No. 29'.

At BM there is a sheet with a section of frond, labelled Asplenium longissimum' and marked 'TYPE'. Blume's name is on it but the collector is unknown; it is from the Kuching Hills, Sarawak, Borneo, and is dated 2 March 1914. This plant agrees with the Leiden type specimens of $A$. acutiusculum and $A$. longissimum.

The holotypes of $A$. acutiusculum and $A$. longissimum agree and should be considered conspecific. As Price (1982) correctly observed, the type of A. acutiusculum has smaller pinnae but otherwise is similar to A. longissimum. Asplenium longissimum Blume should be the accepted name as published by Price (1982).

\section{ASPLENIUM ANISODONTUM AND A. CAUDATUM}

Asplenium anisodontum was described by C. Presl (1849) from a specimen collected by Cuming (Cuming 128) in Luzon, Philippines. Duplicates of Cuming 128 are found at Prague (PR), K, BM and L. Asplenium anisodontum (Cuming 128) duplicates are readily distinguishable from Asplenium longissimum Blume by the length of the frond and the lamina apex. A. longissimum grows fronds up to $2 \mathrm{~m}$ in length whereas those of $A$. anisodontum do not attain $1 \mathrm{~m}$. The frond apex of $A$. longissimum has indeterminate growth and extends into a lash which can take root; that of $A$. anisodontum shows determinate growth and ends in a terminal segment formed by the apparent fusion of the pinnae in the apical region (Table 1). Other differences can be observed in details of the pinnae. The species are clearly different.

Copeland (1960) thinks that A. anisodontum C.Presl is indistinguishable from Asplenium caudatum G.Forst.; Price (1982) places it in the complex of A. caudatum G.Forst.

Holttum (1968) comments that the type specimen of A. anisodontum (Cuming 128) in the herbarium Presl, at Charles University (PRC), Prague, has the 'pinnae distantly sharply toothed, not lobed as in A. caudatum Forster'. The BM herbarium has four sheets of Cuming 128, from Luzon. All four sheets have fertile fronds; one of the sheets is a mixed collection with Tarachia truncatiloba C.Pres1 (Cuming 99). Kew has two sheets, each with one fertile frond, of Cuming 128, also from Luzon. In $\mathrm{L}$ there are two sheets of Cuming 128 from the Philippines, each with a fertile frond. Rosenstock, in 1915, classified them as Asplenium caudatum G.Forst. var. anisodontum Kunze. One sheet with number 'Herb. Lugd. Bat. 908.304-749' has a very old label with the name Asplenium anisodontum; the other sheet, 'Herb. Lugd. Bat. 908.304-750', has been labelled 'isotypus' by C.V. Morton. 
TABLE 1. Differences between Asplenium anisodontum C.Presl, A. Longissimum Blume and A. caudatum G.Forst.

\begin{tabular}{|c|c|c|c|}
\hline & $\begin{array}{l}\text { A. anisodontum } \\
\text { C.Presl }\end{array}$ & $\begin{array}{l}\text { A. longissimum } \\
\text { Blume }\end{array}$ & $\begin{array}{l}\text { A. caudatum } \\
\text { G.Forst }\end{array}$ \\
\hline Frond length & up to $120 \mathrm{~cm}$ & up to $200 \mathrm{~cm}$ & up to $100 \mathrm{~cm}$ \\
\hline Lamina shape & lanceolate & $\begin{array}{l}\text { elongated. } \\
\text { attenuate at both } \\
\text { ends }\end{array}$ & elongate oblong \\
\hline Frond growth & determinate & indeterminate & determinate \\
\hline Apical bud & present & not present & not present \\
\hline Basal pinnae & $\begin{array}{l}\text { not reduced, } \\
\text { distant }\end{array}$ & reduced, distant & $\begin{array}{l}\text { reduced, somewhat } \\
\text { distant }\end{array}$ \\
\hline Pinna & falcate & straight & straight \\
\hline Pinna margin & $\begin{array}{l}\text { toothed to } \\
\text { shallowly lobed, } \\
\text { lobes serrate }\end{array}$ & $\begin{array}{l}\text { bluntly toothed } \\
\text { lobes }\end{array}$ & $\begin{array}{l}\text { lobed } 1 / 2 \quad 1 / 3 \text { to } \\
\text { costa, lobes bluntly } \\
\text { toothed }\end{array}$ \\
\hline Acroscopic basal lobe & $\begin{array}{l}\text { absent or slightly } \\
\text { auricled }\end{array}$ & $\begin{array}{l}\text { auricled on both } \\
\text { sides }\end{array}$ & absent \\
\hline Sori & $\begin{array}{l}\text { one row, oblique, } \\
\text { distant from pinna } \\
\text { base }\end{array}$ & $\begin{array}{l}\text { one row, oblique, } \\
\text { distant from pinna } \\
\text { base }\end{array}$ & $\begin{array}{l}\text { two rows, parallel } \\
\text { and oblique, close } \\
\text { to pinna base }\end{array}$ \\
\hline
\end{tabular}

Georg Forster sent duplicates of Asplenium caudatum collected during his trip to Polynesia to at least six European herbaria (BM, GOET, LIV, MW, S, UPS), but he did not specify the type. At BM there is a well-preserved specimen collected by Forster on the islands of the Pacific Ocean, 'Insulae Oceani Pacifici'. This specimen has been subsequently labelled 'TYPE' at the museum. It consists of one, poorly pressed frond, with the rhizome and lower and middle portion of the stipe missing. The frond is fertile and fully developed. Another Forster specimen is housed at the Lomonosov State University of Moscow (MW). It is labelled 'SYNTYPUS', and was collected in Polynesia.

Asplenium caudatum differs from A. anisodontum in details of the pinnae and soral position (Table 1 ).

A. caudatum can be characterized thus: the lower pinnae gradually reduced; fertile bud absent; pinnae straight; pinna margin lobed with narrow sinuses cutting down $1 / 2-1 / 3$ to the costa; sori in two rows, one row almost parallel to the costa, beginning near the base of pinna. Asplenium anisodontum differs as follows: does not have the lower pinnae reduced; fertile bud present on the rachis; pinnae falcate; pinna margin notched, not lobed; sori in a single row, divergent. and distal from the pinna base. 


\section{DISTRIBUTION AND ECOLOGY}

Asplenium longissimum usually grows at low and middle altitudes near the base of trees, and rarely as an epiphyte close to the ground. It is distributed throughout Vietnam, Thailand, Borneo and the Philippines. Asplenium anisodontum commonly grows above $1000 \mathrm{~m}$ altitude, and is found in Sumatra, Borneo, and the Philippine islands of Mindanao, Panay and Luzon. Asplenium caudatum is a low-altitude fern found in Polynesia. Neither A. longissimum nor A. anisodontum have been collected from Polynesia. The name of Asplenium caudatum G.Forst., as it has been commonly used for Asian and Malesian plants, represents a group of species, and needs further study.

\section{CONCLUSIONS}

It can be concluded from the above observations that Asplenium anisodontum C.Presl is a distinct species, different from $A$. longissimum Blume and from $A$. caudatum G.Forst. In the Philippines, plants of $A$. anisodontum have traditionally been referred to $A$. caudatum, but none of the many Philippine specimens housed at BM or $\mathrm{K}$ agree with the type of $A$. caudatum G.Forst. It is doubtful, therefore, that the true A. caudatum is to be found in the Philippines. Asplenium anisodontum C.Presl was erroneously omitted from the Checklist of Philippine Ferns (Salgado, 1990), and this error should be corrected.

\section{REFERENCES}

BLUME, C. L. (1828). Enumeratio Plantarum Javae et Insularum Adjacentium. Leiden: J.W. van Leeuwen.

CHR ISTENSEN, C. F. A. (1905). Index Filicum. Hafniae (Kobenhavn): H. Hagerup. COPELA ND, E. B. (1960). Fern Flora of the Philippines. Vol. 3. Manila: Nat. Inst. Sci. Tech., Bureau of Printing.

HOLTTUM, R. E. (1968). A commentary on some type specimens of ferns in the Herbarium of K.B. Presl. Novit. Bot. Delect. Seminum Horti Bot. Univ. Carol. Prag. [1968]: 3-57.

PRESL, C. B. (1849). Epimeliae Botanicae, cum tabulis quindecem lithographicis. $A h / l$. König. Böhm. Ges. Wiss. 5: 1-264, t. 1-15.

PRICE, M. G. (1982). The ferns of Steere and Harrington. Contr. Unir. Michigan Herh. 15: 197-204.

SALGADO. A. E. (1990). A checklist of Philippine ferns. Philipp. J. Sci. 119: 107148. 